\title{
SEASONAL VARIATION IN PROPHYLACTIC SECONDARY METABOLITES OF VARTHEMIA CANDICANS IN TWO COASTAL HABITATS IN EGYPT
}

\author{
Fatma A. Ahmed', Mahmoud A. Elhaak ${ }^{2}$, Khalil M. Saad-Allah ${ }^{2}$ and \\ Mohamed I. Kashlana ${ }^{1 *}$ \\ ${ }^{1}$ Medical and Aromatic Plants Department, Desert Research Center, El- \\ Mataria, Cairo, Egypt \\ ${ }^{2}$ Botany Department, Faculty of Science, Tanta University, Tanta, Egypt \\ *E-mail: m_kashlana123@yahoo.com
}

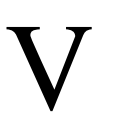

arthemia candicans (Delile) Boiss., naturally grows in the Northwestern costal region of Egypt. The present study was conducted to evaluate the diversity of $V$. candicans secondary metabolites in two habitats during different seasons. Results showed that flavonoids, alkaloids, saponins, and phenolic compounds content attenuated their maximum value during spring in sand dune habitat, however, it reached a peak during summer in Wadi Habbes habitat. HPLC analysis of phenolic compounds from aerial parts showed two common phenolic compounds in both habitats, eight unique phenolic compounds in the plant growing in sand dune, and four phenolic compounds characteristic to Wadi Habbes plants. The high antioxidant activity of the plant was attributed to its high phenolic compounds content.

Keywords: Varthemia candicans, phenolic compounds, alkaloids, medicinal plant, Egypt, HPLC

Nature has bestowed on people a very rich botanical wealth and a large number of naturally occurring plants in different parts of the world. Natural products from plant resources, including bio-molecules and secondary metabolites, usually exhibit some kind of biological activities in traditional and modern medicine. Due to their immense healing properties, plants are widely used in the human therapy, veterinary, agriculture, scientific research and in countless other areas (Kandukuri et al., 2009 and Varalakshmi et al., 2011).

The flora of Egypt comprises about 2165 species of plants distributed in different localities that vary in type of soil and prevailing climatic and other environmental conditions support a wide range of plant species. In addition, many plants have been successfully introduced and naturalized in Egypt (Boulos, 2005 and Haggag, 2009). Medicinal plants of Egypt represent an important source for investigations of antioxidants as 
medically important compounds. The medicinal value of these plants lies in some active chemical substances that produce a definite physiological action on the human body. The most important of these bioactive constituents of plants are alkaloids, tannins, flavonoids, terpenoids and phenolic compounds (Edeoga et al., 2005).

The genus Varthemia is a member of Asteraceae, that encompasses about five species distributed throughout the Mediterranean region (Bremer, 1994). In Egypt, the genus Varthemia encompasses three species namely $V$. candicans, V. montana and V. iphionoides (Täckholm, 1974). Varthemia candicans is an aromatic perennial herb, that inhibits rocky places, semidryland and sand dunes (El-Kady, 1993).

Biochemical studies on the different species of the genus Varthemia led to the isolation of volatile constituents (Romero et al., 2003), squiterpenes (Sanchez et al., 2000 and Benito et al., 2002), monoterpenes (Ahmed and Jakupovic, 1990) and flavonoids (Rubio et al., 1995). To date, very few/or no phytochemical studies on $V$. candicans have been reported, although this genus was the subject of several chemical investigations. Some Varthemia species have antiprotozoal (Villaescusa et al., 2000), antimicrobial (Hammerschmidt et al., 1993), anti-inflammatory (Benito et al., 2002) and antidiabetic activities (Al-Howiriny et al., 2005).

The present study aimed to evaluate the antioxidative potential of $V$. candicans aerial parts inhibiting rocky places and loosely-attached sandy places in the Northwestern coastal region of Egypt during different growth seasons. Antioxidative potential in this study is represented in the pharmacologically active secondary metabolites including flavonoids, alkaloids, saponins and phenolic compounds.

\section{MATERIALS AND METHODS}

\section{Collection of Plant Materials}

The aerial parts of $V$. candicans were collected during 2011-2012 throughout the growth seasons (winter, spring, summer and autumn) from Wadi Habbes (master upstream rocky habitats), and oolitic sand dunes. The plant samples were washed with tap water thwice, followed by distilled water. The samples were then oven-dried at $60^{\circ} \mathrm{C}$ for five days. The dried samples were ground to fine powder, sieved through $0.2 \mathrm{~mm}$ sieve and stored in paper bags for further analysis.

The ethanolic extract was prepared by immersing the dry powders in $80 \%$ ethanol for six hours, filtered through Whatman No. 1 filter paper. The residues were re-extracted again for more 2 times as previous and the clear supernatants were collected, combined and completed into definite volume. 


\section{Phytochemical Analysis}

The obtained ethanolic extract $(80 \%)$ was used for the quantification of secondary metabolites. Total flavonoids content was estimated by aluminum chloride colorimetric method according to Chang et al. (2002). The total alkaloids content was evaluated spectrophotometrically according to the method by Shamsa et al. (2008). Total saponin content was estimated quantitatively by the method described by Hiai et al. (1975). Total phenolic compounds content was estimated quantitatively using the method adopted by Jindal and Singh (1975).

\section{HPLC Analysis of Phenolic Compounds}

Phenolic compounds of plant sample were extracted according to the method outlined by Ben-Hammouda et al. (1995). The samples were filtered through a $0.22 \mu \mathrm{m}$ filter membrane (Millipore, UK) prior to HPLC analysis. $50 \mu \mathrm{l}$ of the sample (diluted accordingly) was injected onto hypersil $\mathrm{C}_{18}$ reversed-phase column (250 x $4.6 \mathrm{~mm})$ (Dionex Ultimate 3000 UHPLC) connected with Diode array Detector (Chromeleon 7.1.1.1127).

A constant flow rate of $1.2 \mathrm{ml} / \mathrm{min}$ was used with two mobile phases: (A) 5\% acetic acid in distilled water at $\mathrm{pH}$ (2.65) and (B) $0.5 \%$ acetic acid in $99.5 \%$ acetonitrile. The elution gradient was linear, starting with (A) and ending with (B) over 35 minutes. Phenolic compounds were detected by UV detector set at wavelength $254 \mathrm{~nm}$. Phenolic compounds of each sample were identified by comparing their relative retention times with those of the standers mixture chromatogram. The concentration of an individual compound was calculated on the basis of peak area measurements, and then converted to $\mu \mathrm{g}$ phenolic $\mathrm{g}^{-1}$ dry weight. All chemicals and solvents used were HPLC spectral grade (Sigma-Aldrich).

\section{Evaluation of Total Antioxidant Activity}

A procedure slightly modified from the method reported by BrandWilliams et al. (1995) and Bondet et al. (1997) was followed to evaluate the antioxidant capacity of the ethanolic extract using DPPH radical.

\section{Statistical Analysis}

Statistical analysis of the obtained results was carried out according to the technique adopted by Norusis (2007). Data were analyzed by one-way ANOVA with the Duncan's multiple range test (DMRT) to separate means with significance levels at $\mathrm{P} \leq 0.05 \%$. All statistical analyses were carried out using SPSS 19.0 software. The results are represented as the mean of three replicates \pm standard deviation. 


\section{RESULTS AND DISCUSSION}

\section{Total Flavonoids Content}

The total flavonoids content of $V$. candicans aerial parts collected from Wadi Habbes (WH) and Sand Dunes (SD) habitats at the different growth seasons is represented in fig. (1). Total flavonoids varied significantly with habitat, growth season and their interaction. Total flavonoids of $V$. candicans in WH increased from winter to autumn but this increase was slight in autumn. Flavonoids content in this habitat fluctuated between a maximum $\left(8.2 \mathrm{mg} \mathrm{g}^{-1} \mathrm{~d} \mathrm{wt}\right)$ at summer and a minimum $(3.41 \mathrm{mg} \mathrm{g}$ ${ }^{1} \mathrm{~d} \mathrm{wt}$ ) in winter. The flavonoids content of $V$. candicans in WH habitat was greater by $100.3 \%, 139.9 \%$ and $112.9 \%$ in spring, summer and autumn in comparison with winter, respectively. In the SD habitat, the total flavonoids content of $V$. candicans increased prominently from winter to spring and summer seasons, but the increase was attenuated by autumn season. Flavonoids content varied from its maximum $\left(12.2 \mathrm{mg} \mathrm{g}^{-1} \mathrm{~d} \mathrm{wt}\right)$ in the spring to its minimum ( $\left.4.7 \mathrm{mg} \mathrm{g}^{-1} \mathrm{~d} \mathrm{wt}\right)$ in the winter. The flavonoids content oscillation in SD habitat was 162.4, 149.6 and $7.3 \%$ higher in spring, summer and autumn, respectively as compared to that in winter.

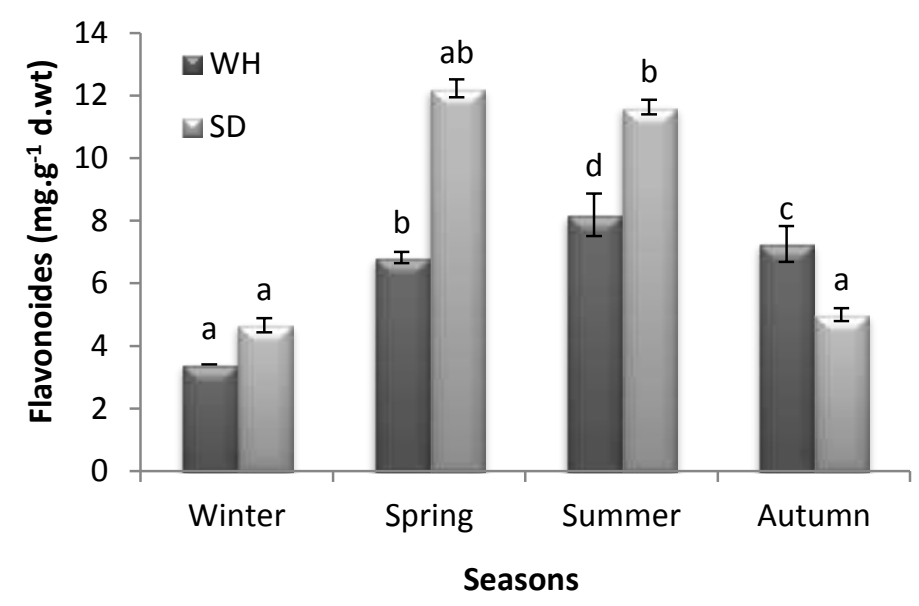

Fig. (1). Variation in total flavonoids content of $V$. candicans aerial parts as a function of growth habitat (WH and SD) and growth season.

The two columns with the same letter are non-significant, while columns with different letters are statistically significant.

Plants contain different polyphenolic compounds, e.g. flavonoids, phenolic acids, coumarins and anthocyanins and their content and composition is strongly influenced by different factors (Weidner and Paprocka, 1996). Polyphenols are involved in the defense mechanism of 
plants and their levels are enhanced by both biotic and abiotic stress (Dudjak et al., 2004). Flavonoids are important dietary compounds, having a capacity to inhibit DNA damage and lipid peroxidation and quench oxygen radicals (Kinoshita et al., 2005). They also improve high blood pressure, anticancer, antimicrobial, antioxidant, antibiotic and antiallergy actions (Kinoshita et al., 2005). Flavonoids are able to function as chelators for metals, depending on the molecular structure (Michalak, 2006 and Korkina, 2007).

\section{Total Alkaloids Content}

Fig. (2) represents the change in the total alkaloids content in the aerial parts of $V$. candicans growing in $\mathrm{WH}$ and SD habitats. With respect to WH habitat, the total alkaloids content increased gradually from winter till summer season then suddenly decreased in autumn season. The highest content $(17.7 \mathrm{mg}$ g-1 d wt) was detected in summer season and the lowest content (7.7 mg g-1 d wt) was observed in winter season. In SD habitat the total alkaloids content of the $V$. candicans aerial parts was duplicated from winter to spring season then decrease gradually till autumn season. The highest alkaloids content $\left(18.3 \mathrm{mg} \mathrm{g}_{-1} \mathrm{~d} \mathrm{wt}\right)$ was detected in the spring season, and the lowest alkaloids content $(9.2 \mathrm{mg} \mathrm{g}-1 \mathrm{dwt})$ was in autumn season.

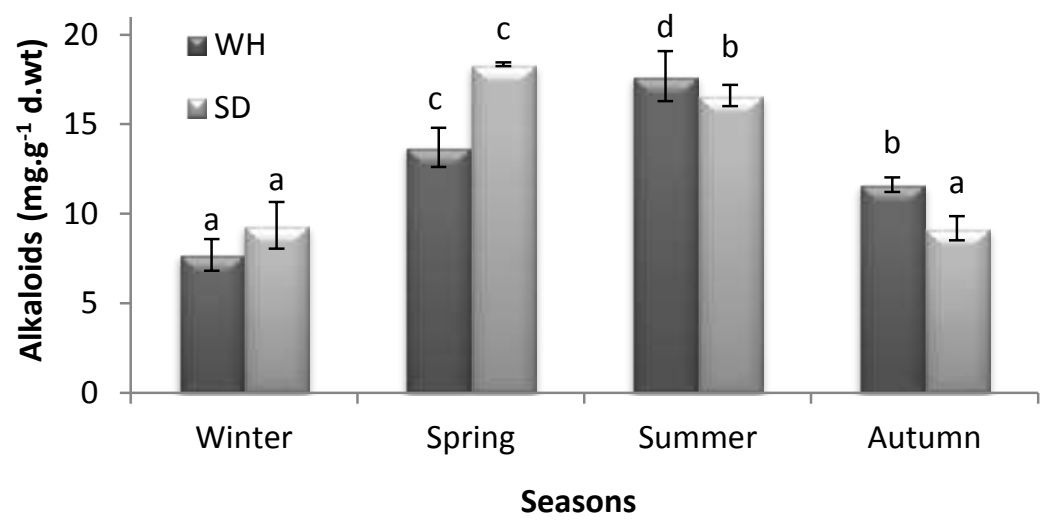

Fig. (2). Variation in total alkaloids content of $V$. candicans aerial parts as a function of growth habitat (WH and SD) and growth season.

The two columns with the same letter are non-significant, while columns with different letters are statistically significant.

Many secondary metabolites play an important function as chemical defense compounds against herbivores, microbes or competing plants (Wink, 1997). One of the largest groups of chemical arsenals produced by plants is the alkaloids. Many of these alkaloids metabolic by-products are derived from amino acids and include an enormous number of nitrogenous 
compounds. Some plant alkaloids intensely affect herbivores and are involved in a variety of natural plant-insect interactions (Brown and Trigo, 1995). Alkaloids have important eco-chemical functions in the defense of the plant against pathogenic organisms and herbivores or, as in the case of pyrrolizidine alkaloids, as pro-toxins for insects, which further modify the alkaloids and then incorporate them into their own defense secretions (Hartmann, 1991). The function of alkaloids in plants is still largely obscure, although individual substances have been reported to be involved as growth regulators or insect repellents or attractants (Hegnauer, 1967). Some organisms use alkaloids for protection as Ornate Moth, pyrrolizidine alkaloids render these larvae and adult moths unpalatable to many of their natural enemies like coccinelid beetles, green lacewings, insectivorous hemiptera and insectivorous bats (Conner, 2009).

\section{Saponin Content}

The saponin content of $V$. candicans aerial parts in $\mathrm{WH}$ and SD habitats showed considerable variations in response to the change in the habitat and growth seasons (Fig. 3). The saponin content in $V$. candicans aerial parts in WH habitat increased six-folds from winter to summer season then markedly decreased at autumn season to about three-folds than summer season value. The highest saponin content $\left(32.30 \mathrm{mg} \mathrm{g}^{-1} \mathrm{~d} \mathrm{wt}\right)$ was recorded in summer season. While, the lowest saponin content $\left(5.39 \mathrm{mg} \mathrm{g}^{-1} \mathrm{~d}\right.$ wt) was recorded in winter season.

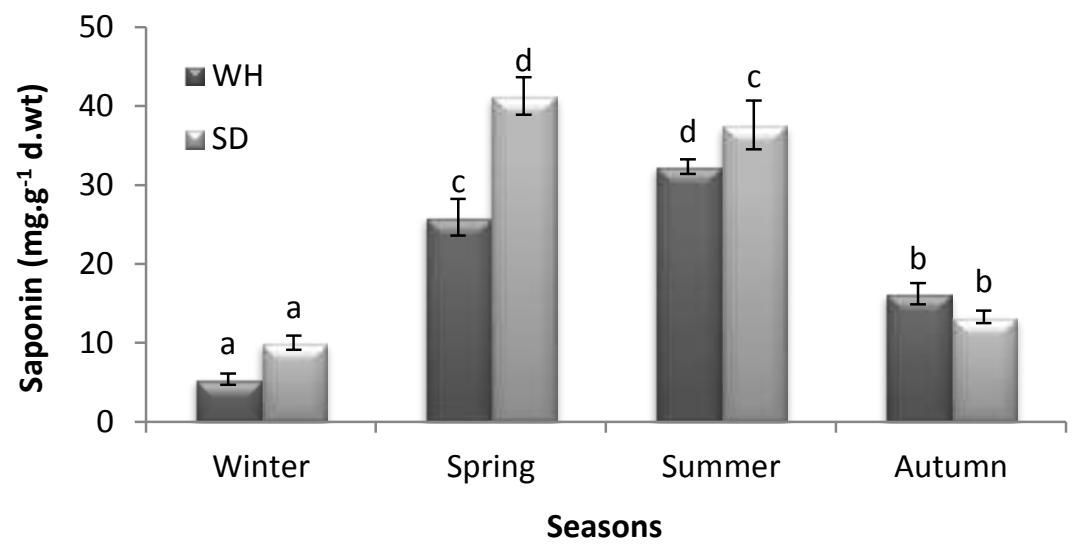

Fig. (3). Variation in total saponins content of $V$. candicans aerial parts as a function of growth habitat (WH and SD) and growth season.

The two columns with the same letter are non-significant, while columns with different letters are statistically significant.

In SD habitat, saponin content of $V$. candicans aerial parts increased at spring season about four-folds than winter season value, then saponin 
content decreased gradually till autumn season. The saponin content was $41.28 \mathrm{mg} \mathrm{g}^{-1} \mathrm{~d}$ wt in spring season as a maximum and was $10.0 \mathrm{mg} \mathrm{g}^{-1} \mathrm{~d} \mathrm{wt}$ in winter season as a minimum value.

Saponins are naturally occurring surface-active glycosides. They are mainly produced by plants, but also by lower marine animals and some bacteria (Yoshiki et al., 1998). A number of factors, such as physiological age, environmental and agronomic factors, have been shown to affect the saponin content of plants (Yoshiki et al., 1998). Many saponins are known to be antimicrobial, to inhibit mould, and to protect plants from insect attack. Saponins may be considered a part of plant's defense systems, and as such have been included in a large group of protective molecules found in plants named 'phytoanticipins' or 'phytoprotectants' (Morrissey and Osbourn, 1999). It has also been suggested that saponins could be a source of monosaccharides (Barr et al., 1998). Saponins are valuable compounds to humans due to their use in pharmacy, industry, cosmetics, agriculture and the food market (Fenwick and Oakenfull, 2006 and Sun et al., 2009). Saponins have various effects that are attributed to a diverse range of properties, some of which induce both beneficial and detrimental effects on human health such as pesticidal, insecticidal and molluscicidal activity, allelopathic action, antinutritional effects, sweetness and bitterness (Hostettmann and Marston, 1995). Also saponins are useful in the human diet for controlling cholesterol, where it forms strong insoluble complexes with cholesterol resulting in lowering cholesterol activity in humans. Low saponin content of the diet may be partly responsible for the high incidences of heart disease in Western countries (Oakenfull and Sidhu, 1990). Saponins if repeatedly included in the diet may help the body protect itself from cancer.

\section{Total Phenolics Content}

The amount of total phenolics varied significantly in $V$. candicans aerial parts by the variation in the growth season and interaction of seasons with habitat but not significantly varied by the variation in habitation (Fig. 4). Total phenolics content of $V$. candicans in WH slightly varied from those of SD habitat during the different growth seasons. In WH habitat, total phenolics increased contentiously from winter till summer then decreased in autumn season. However, the furthermost content of phenolics of plant aerial parts in WH (30.6 mg g-1 $\mathrm{d} \mathrm{wt}$ ) was recorded in summer season, at the same time as the least phenolic content $\left(25.7 \mathrm{mg} \mathrm{g}^{-1} \mathrm{~d} \mathrm{wt}\right)$ was recorded in the winter season.

In the SD habitat the plant phenolic content increased from winter till spring then decreased through summer and autumn seasons. The highest phenolic content was $31.8 \mathrm{mg} \mathrm{g}^{-1} \mathrm{~d}$ wt during spring and the lowest content was $27.9 \mathrm{mg} \mathrm{g}^{-1} \mathrm{~d}$ wt during autumn season. 


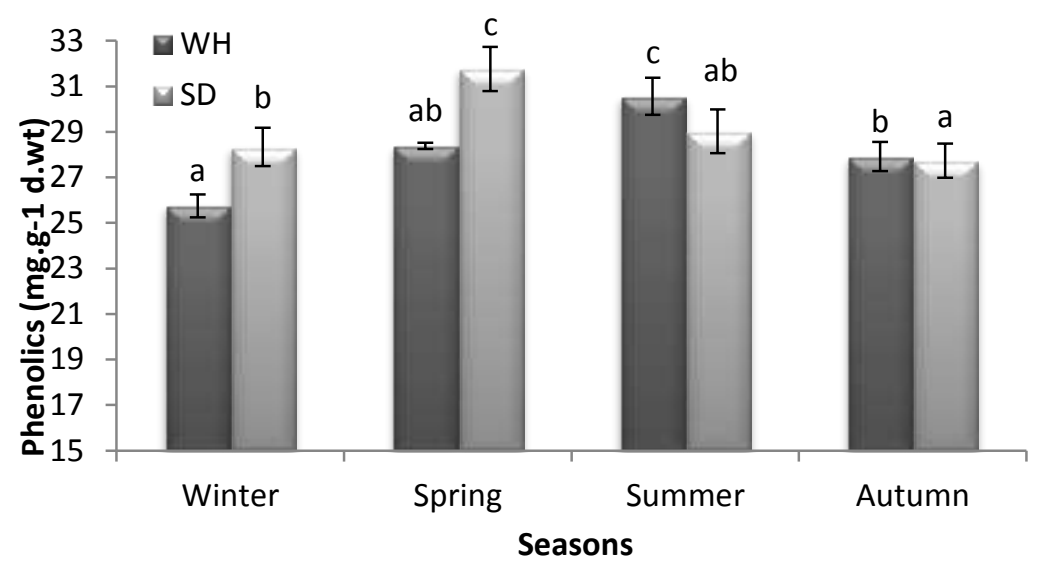

Fig. (4). Variation in total phenolics content of $V$. candicans aerial parts as a function of growth habitat (WH and SD) and growth season.

The two columns with the same letter are non-significant, while columns with different letters are statistically significant.

\section{HPLC Identification of Phenolic Compounds}

Quantitative and qualitative estimation of the phenolic compounds of $V$. candicans aerial parts in WH and SD habitats was achieved using HPLC. Compounds were separated, identified using authentic compounds and their concentration was determined (Table 1). The separated and identified phenolic compounds in $V$. candicans were fourteen, named, tannic acid, gallic acid, pyrocatechol, phananthrene, nicotinic acid, resorcinol, OHbenzoic acid, chlorogenic acid, phenol, vanillin, $\rho$-coumaric acid, ferulic acid, salicylic acid, and rutin.

The analysis data showed that, only two phenolic compounds, (phananthrene and nicotinic acid) were detected in $V$. candicans in both habitats (WH and SD). Phananthrene content was 7.26\% in SD and 8.29\% in WH. However, nicotinic acid content was $1.61 \%$ in SD and $4.33 \%$ in WH habitat, indicating higher percentage of the two phenolic compounds in $V$. candicans of $\mathrm{WH}$ habitat. In addition, $V$. candicans growing in this habitat was characterized by the presence of four distinctive phenolic compounds. These phenolic compounds in descending order according to their percentage are tannic acid (71.55\%), resorcinol (7.51\%), pyrocatechol $(5.17 \%)$ and gallic acid (3.19\%).

On the other hand, $V$. candicans growing in SD habitat showed anotherpattern of phenolic compounds content, where it is characterized by the presence of ten distinctive phenolic compounds not found in the plants growing in WH habitat. The percentage of those phenolics components in those habitats varied from $19.39 \%$ ( $\rho$-coumaric acid) to $3.48 \%$ (phenol). 
Table (1). The percentage of detected phenolic compounds in V. candicans aerial parts in Wadi Habbes (WH) and Sand Dunes (SD) habitats by HPLC.

\begin{tabular}{cclcc}
\hline \multirow{2}{*}{ Peak } & \multirow{2}{*}{\begin{tabular}{c}
\multirow{2}{*}{ (min.) } \\
\end{tabular}} & Compound & \multicolumn{2}{c}{ Habitat \% } \\
\cline { 4 - 5 } & 1.417 & Tannic acid & WH & SD \\
\hline 1 & 1.780 & Gallic acid & 3.55 & ND \\
2 & 1.967 & Pyrocatechol & 5.17 & ND \\
3 & 2.730 & Phananthrene & 8.29 & 7.26 \\
4 & 3.067 & Nicotinic acid & 4.33 & 1.61 \\
5 & 5.033 & Resorcinol & 7.51 & ND \\
6 & 9.820 & OH-benzoic acid & ND & 7.76 \\
7 & 10.077 & Chlorogenic acid & ND & 6.45 \\
8 & 11.067 & Phenol & ND & 3.48 \\
9 & 14.133 & Vanillin & ND & 8.69 \\
10 & 14 & ND & 19.39 \\
11 & 16.160 & $\rho$-coumaric acid & ND & 10.43 \\
12 & 16.973 & Ferulic acid & ND & 7.73 \\
13 & 17.367 & Salicylic acid & ND & 10.33 \\
14 & 18.213 & Rutin & \multicolumn{2}{c}{}
\end{tabular}

Phenolic compounds give the plant an important value as they exhibit a wide range of physiological properties, such as anti-allergenic, antiartherogenic, anti-inflammatory, anti-microbial, antioxidant, anti-thrombotic, cardioprotective and vasodilatory effects (Middleton et al., 2000; Puupponen-Pimia et al., 2001; Manach et al., 2005). Also, phenolic compounds could be a major determinant of antioxidant potentials of foods and could therefore be a natural source of antioxidants. Some phenolic compounds recorded in the study plant have medical importance such as:

1. Gallic acid has high antioxidant capacity, significantly higher than any other antioxidant and about five times higher than Vitamin $\mathrm{C}$ in juice of apple (Sakagami and Satoh, 1997).

2. Ferulic acid and gallic acid inhibit the mycelial growth of Fusarium spp. by $85.1 \%$, where it can decrease the damping off (Ahtiainen et al., 2003).

3. Tannic acid was used as a treatment for many toxic substances, such as strychnine, mushroom, and ptomaine poisonings (Sturmer, 1999).

4. Nicotinic acid has been used for over 50 years to increase levels of high density lipoproteins (HDL) in the blood and has been found to decrease the risk of cardiovascular events modestly in a number of controlled human trials (Bruckert et al., 2010).

5. Salicylic acid is known for its ability to ease aches and pains and reduce fevers (Madan and Levitt, 2014). 
6. $p$-Coumaric acid has antioxidant properties and is believed to reduce the risk of stomach cancer (Ferguson et al., 2005) by reducing the formation of carcinogenic nitrosamines (Kikugawa et al., 1983). Also, p-coumeric acid has been found to help honey bees to detoxify certain pesticides (Mao et al., 2013).

7. Rutin inhibits platelet aggregation (Navarro-Nunez et al., 2008) as well as it decreases capillary permeability, making the blood thinner and improving circulation. Recent studies confirm rutin could help in preventing blood clots, so could be used to treat patients at risk of heart attacks and strokes (Reporter, 2012).

\section{Antioxidant Scavenging Activity}

The percentages of antioxidant scavenging activity of $V$. candicans aerial parts in $\mathrm{WH}$ and $\mathrm{SD}$ habitats at the various growth seasons are represented in fig. (5). The antioxidant activity of the ethanolic extract in WH habitat showed slight fluctuation, where it decreased from winter to spring season, then showed an increase during summer season then, redecreased at autumn season to its lowest value. The antioxidant scavenging activity of $V$. candicans aerial parts mostly remained constant all over the plant growth seasons throughout this habitat, it showed a maximum $87.97 \%$ activity in the summer season and a minimum $81.391 \%$ one in the autumn season.

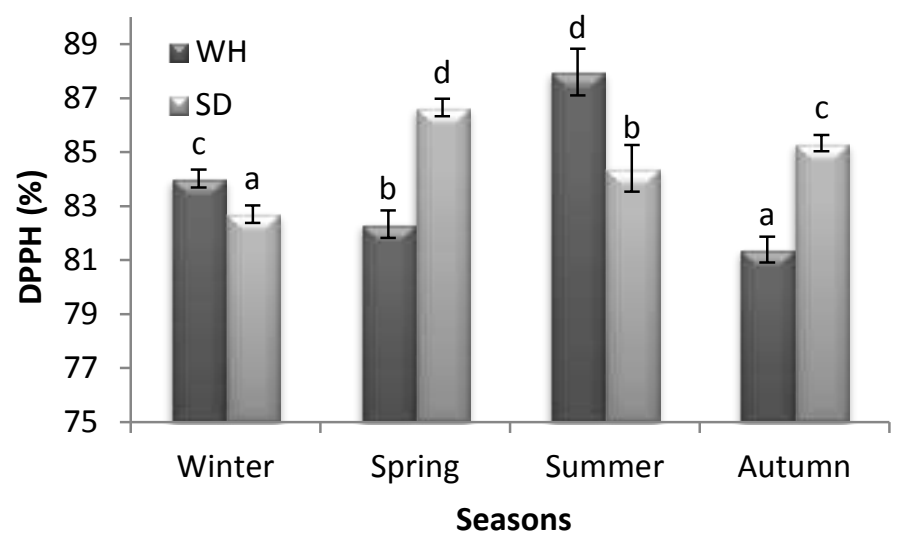

Fig. (5). Variation in antioxidant scavenging activity (\%) of $V$. candicans aerial parts as a function of growth habitat (WH and SD) and growth season.

The two columns with the same letter are non-significant, while columns with different letters are statistically significant. 
In the SD habitat, the percentage of antioxidant scavenging activity of $V$. candicans also fluctuated with an increasing trend from winter to autumn with a marked increase in spring season. It showed slight change between a maximum of $86.654 \%$ in the spring and a minimum of $82.707 \%$ in the winter season. The antioxidant scavenging activity is the most commonly used method for assessment of the antioxidant properties and strongly correlated with phenolic compounds (Maisuthisakul et al., 2007). Many authors (Sanita et al., 1998 and Dong et al., 2006) reported an increase in the total antioxidants scavenging activity in plants to cope with abiotic stress conditions. Adamo et al. (2004) have pointed out that some environmental conditions are capable of breaking the chemical bonds of polyphenols, thereby releasing soluble phenols of low molecular weights, leading to an increase of antioxidant capacity.

\section{CONCLUSION}

The coastal regions around the world contain a wide range of wild plants with obscure medicinal importance. Such plants contain great diversity of phytochemicals with a great potential in treating many chronic diseases. Thus further studies are still required to explore the phytochemically active ingredients of such plants at their natural habitats throughout the growth seasons to maximize the benefit from these natural resources. $V$. candicans, as a wild plant, showed high content of medicinally important phytochemicals in its aerial parts. The harvest time varies according to the season and habitat in order to obtain the uppermost quantity of such compounds. In the rocky places, the best time for harvest was during summer season, but in the sandy places it is suggested during the spring season.

\section{REFERENCES}

Adamo, M., D. Capitani, L. Mannina, M. Cristinzio, P. Ragni, A. Tata and R. Coppola (2004). Truffles decontamination treatment by ionizing radiation. Radiation Physics and Chemistry, 71: 165-168.

Ahmed, A.A. and J. Jakupovic (1990). Sesqui-and monoterpenes from Jasonia montana. Phytochemistry, 29: 3658-3661.

Ahtiainen, J., M. Aalto, and P. Pessala (2003). Biodegradation of chemicals in a standardized test in environmental conditions. Chemosphere, 51 (6): 529-537.

Al-Howiriny, T.A., A.J. Al-Rehaily, J.R. Polsc, J.R. Porter, J.S. Mossa and B. Ahmed (2005). Three new diterpenes and the biological activity of different extracts of Jasonia montana. Natural Product Research, 19: 253-265. 
Barr, I.G., A. Sjolander and J.C. Cox (1998). ISCOMs and other saponin based adjuvants (Review). Advanced Drug Delivery Reviews, 32: 247-271.

Ben-Hammouda, M., R.J. Kremer, H.C. Minor and M. Sawar (1995). A chemical basis for different potential of sorghum hybrids on wheat. Journal of Chemical Ecology, 21: 775-786.

Benito, P.B., M.J. Abad, A.M. Diaz, L. Villaescusa, M.A. Gonzalez and A.M. Silvan (2002). Sesquiterpenes from Jasonia glutinosa. Biological and Pharmaceutical Bulletin, 25: 1-4.

Bondet, V., W. Brand-Williams and C. Berset (1997). Kinetics and mechanisms of antioxidant activity using the DPPH free radical method. Lebensmittel-Wissenschaft and-Technologie. Food Science and Technology, 30: 609-615.

Boulos, L. (2005). In "Flora of Egypt". Vol. (4). Al Hadara Publishing, Cairo, Egypt. 525 pp.

Brand-Williams, W., M.E. Cuvelier and C. Berset (1995). Use of a free radical method to evaluate antioxidant activity. LebensmittelWissenschaft and Technologie. Food Science and Technology, 28: 25-30.

Bremer, K. (1994). In "Asteraceae: Cladistics and Classification". Timber Press, Portland, OR., 10: 295-304.

Brown, K.S. and J.R. Trigo (1995). In "The Ecological Activity of Alkaloids", (Ed. G.A. Cordell). Academic Press, San Diego, 47: 227-354.

Bruckert, E., J. Labreuche and P. Amarenco (2010). Meta-analysis of the effect of nicotinic acid alone or in combination on

cardiovascular events and atherosclerosis. Atherosclerosis, 210 (2): 353361.

Chang, C., M. Yang, H. Wen and J. Chern (2002). Estimation of total flavonoid content in propolis by two complementary colorimetric methods. Journal of Food Drug Analaysis, 10: 178-182.

Conner, W.E. (2009). In"Tiger Moths and Woolly Bears-behaviour, Ecology, and Evolution of the Arctiidae". New York: Oxford University Press, p. 1-10.

Dong, J., F. Wu and G. Zhang (2006). Influence of cadmium on antioxidant capacity and four microelement concentrations in tomato seedlings (Lycopersicon esculentum). Chemosphere, 64: 1659-1666.

Dudjak, J., J. Lachman, D. Miholova, D. Kolihova and V. Pivec (2004). Effect of cadmium on polyphenol content in young barley plants (Hordeum vulgare L.). Plant, Soil and Environment, 50: 471-477.

Edeoga, H.O., D.E. Okwu and B.O. Mbaebie (2005). Phytochemical constituents of some Nigerian medicinal plants. African Journal of Biotechnology, 4 (7): 685- 688. 
El-Kady, H.F. (1993). The ruderal vegetation of the Mediterranean desert of Egypt. Feddes Repertorium, 140 (5-6): 403-415.

Fenwick, D.E. and D. Oakenfull (2006). Saponin content of food plants and some prepared foods. Journal of the Science of Food and Agriculture, 34: 186-191.

Ferguson, L.R., Z. Shuo tun and P.J. Harris (2005). Antioxidant and antigenotoxic effects of plant cell wall hydroxycinnamic acids in cultured HT-29. Molecular Nutrition and Food Research, 49 (6): 585-693.

Haggag, M.Y. (2009). In "Herbal Medicine in Egypt". Mediterraneanes CIHAM-Option, p. 45-55.

Hammerschmidt, F.J., A.M. Clark, F.M. Soliman, E.A. El-Kashoury, M.M. Abd El-Kawy and A.M. El-Fishawy (1993). Chemical composition and antimicrobial activity of essential oils of Jasonia candicans and J. montana. Planta Medica, 59: 68-70.

Hartmann, T. (1991). In "Alkaloids in Herbivores: Their Interactions with Secondary Plant Metabolites", (Ed. G.R. Rosenthal and M. Berenbaum). New York: Academic Press, 1: 79-121.

Hegnauer, R. (1967). In "Comparative Phytochemistery of Alkaloids: In Comparative Phytochemistery", (Ed. Swain. T). Academic Press, London, p. 211-230.

Hiai, S., H. Oura, H. Hamanake and Y. Odakea (1975). A colour reaction of penaxadiol with vanillin and sulfuric acid. Planta medica, 28: 131.

Hostettmann, K.A. and A. Marston (1995). In "Saponins. Chemistery and Pharmacology of Natural Products". Cambridge University Press, Cambridge, UK.

Jindal, K.K. and R.N. Singh (1975). Phenolic content in male and female of Carica papaya: A possible physiological marker for sex identification of vegetable seedlings. Physiologia Plantarum, 33: 104-107.

Kandukuri, V., V.G. Jakku, S. Aruri and C.M.A. Singara (2009). Biomolecular and phytochemical analyses of three aquatic angiosperms. Microbiology Research, 3 (8): 418-421.

Kikugawa, K., T. Hakamada, M. Hasunuma and T. Kurechi (1983). Reaction of $p$-hydroxycinnamic acid derivatives with nitrite and its relevance to nitrosamine formation. Journal of Agricultural and Food Chemistry, 1 (4): 780-785.

Kinoshita, T., Z. Lepp and H. Chuman (2005). Construction of a novel database for flavonoids. Journal of Medical Investigation, 52 (1): 291-292.

Korkina, L.G. (2007). Phenylpropanoids as naturally occurring antioxidants: From plant defense to human health. Cellular and Molecular Biology, 53: 15-25. Madan, R.K. and J. Levitt (2014). A review of 
toxicity from topical salicylic acid preparations. Journal of the American Academy of Dermatology, 70 (4): 788-792.

Maisuthisakul, P., R. Pongsawatmanit and M.H. Gordon (2007). Assessment of phenolic content and free-radical scavenging capacity of some Thai indigenous plants. Food Chemistry, 100: 1409-1418.

Manach, C., G. Williamson, C. Morand, A. Scalbert and C. Remesy (2005). Bioavailability and bioefficacy of polyphenols in humans. I. Review of 97 bioavailability studies. American Journal of Clinical Nutrition, 81: 230S-242S. Mao, W., M.A. Schuler and M.R. Berenbaum (2013). Honey constituents up-regulate detoxification and immunity genes in the western honey bee Apis mellifera. Proceedings of the National Academy of Sciences of the United States of America, 110: 8842.

Michalak, A. (2006). Phenolic compounds and their antioxidant activity in plants growing under heavy metal stress. Polish Journal of Environmental Studies, 15: 523-530.

Middleton, E., C. Kandaswami and T.C. Theoharides (2000). The effects of plant flavonoids on mammalian cells: implications for inflammation, heart disease and cancer. Pharmacological Reviews, 52: 673-751.

Morrissey, J.P. and A.E. Osbourn (1999). Fungal resistance to plant antibiotics as a mechanism of pathogenesis. Microbiological and Molecular Biological Reviews, 63: 708-724. Navarro-Nunez, L., M. Palomo, C. Martinez, V. Vicente, J. Castillo, O. Benavente-Garcia, M. Diaz-Ricart, G. Escolar and J. Rivera (2008). Apigenin inhibits platelet adhesion and thrombus formation and synergizes with aspirin in the suppression of the arachidonic acid pathway. Journal of Agricultural and Food Chemistry, 56 (9): 2970-2976.

Norusis M.J. (2007). In "SPPS 15.0 Advanced Statistical Procedures". Upper Saddle, River N J: Prentice Hall.

Oakenfull, D. and G. Sidhu (1990). Saponins - A useful treatment for hyperchlesterolamia. European Journal of Clinical Nutrition, 44: 7988.

Puupponen-Pimia, R., L. Nohynek, C. Meier, M. Kahkönen, M. Heinonen, A. Hopia and K.M. Oksman-Caldentey (2001). Antimicrobial properties of phenolic compounds from berries. Journal of Applied Microbiology, 90: 494-507. Reporter, D.M. (2012). In "Chemical Found in Apples, Onions and Green Tea Can Help Beat Blood Clots". London.

Romero, M.A.G., L.V. Castillo, A.M.D. Lanza, J.M.A. Bricio, C.A.S. Monzon and J.S. Perucha (2003). Volatile oil composition of Jasonia glutinosa. Journal of Biosciences, 58: 804-806.

Rubio, B., L. Villaescusa, A.M. Diaz, L. Fernandez and T. Martin (1995). Flavonol glycosides from Scolymus hispanicus and Jasonia glutinosa. Planta Medica, 61: 583-587.

Egyptian J. Desert Res., 66, No. 1, 1-16 (2016) 
Sakagami, H. and K. Satoh (1997). Prooxidant action of two antioxidants: ascorbic acid and gallic acid. Anticancer Research, 17: 221-224.

Sanchez, R., L. Villaescusa, M. Bernabe and A.M. Diaz (2000). Two new eudesmane alcohols from Jasonia glutinosa. Journal of Biosciences, 55: 693-696.

Sanita, L., D. Toppi, M. Lambardi, L. Pazzagli, G. Cap-pugi, M. Durante and R. Gabbrielli (1998). Response to cadmium in carrot in vitro plants and cell suspension cultures. Plant Science, 137: 119-129.

Shamsa, F., H. Monsef, R. Ghamooshi and M. Verdian-rizi (2008). Spectrophotometric determination of total alkaloids in some Iranian medicinal plants. Thai Journal of Pharmaceutical Sciences, 32: 1720.

Sturmer, J.W. (1999). In "Pharmaceutical Toxicology". The Pharmaceutical Era, 21: 472-474.

Sun, H.X., Y. Xie and Y.P. Ye (2009). Advances in saponin-based adjuvants. Vaccine, 27: 1787-1796.

Täckholm, V. (1974). In "Student's Flora of Egypt", Cairo University Press, Beirut, $562 \mathrm{pp}$.

Varalakshmi, K., C. Sangeetha, U. Samee, G. Irum, H. Lakshmi and S. Prachi (2011). In vitro safety assessment of the effect of five medicinal plants on human peripheral lymphocytes. Tropical Journal of Pharmaceutical Research, 10 (1): 33-40.

Villaescusa, L., A.M. Diaz, M. Gasquet, F. Delmas, E. Ollivier, M.F.R. Bamabe, R. Elias and G. Balansard (2000). Antiprotozoal activity of sesquiterpenes from Jasonia glutinosa. Pharmaceutical biology (Lisse, Netherlands), 38: 176-180.

Weidner, S. and J. Paprocka (1996). Phenolic acids and dormancy in oat (Avena sativa L.) and rye (Secale cereale L.) caryopses. Acta Physiologiae Plantarum, 18: 277-286.

Wink, M. (1997). Compartmentation of secondary metabolites and xenobiotics in plant vacuoles. Advances in Botanical Research, 25: 141-169.

Yoshiki, Y., S. Kudou and K. Okubo (1998). Relationship between chemical structures and biological activities of triterpenoid saponins from soybean (Review). Bioscience Biotechnology and Biochemistry, 62: 2291-2299.

Received: 4/3/2016

Accepted: 19/4/2016 


\section{التغيرات الموسمية في محتوى الأيض الثانوي ذات الأثر الطبي في المجموع

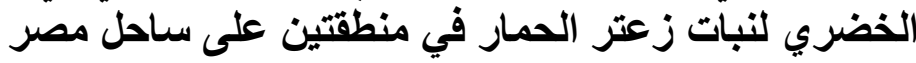

$$
\begin{aligned}
& \text { فاطمة علي أحمد'، محمود أبوزيد عبد الحق'، خليل محفوظ سعد الله ، عحم إبراهيم ححمد } \\
& \text { "' قشلانهـ' } \\
& \text { 'قسم النباتات الطبية والعطرية، مركز بحوث الصحر اه، المطرية، القاهرة، مصر }
\end{aligned}
$$

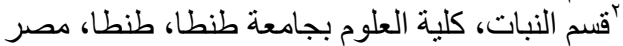

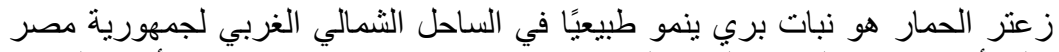

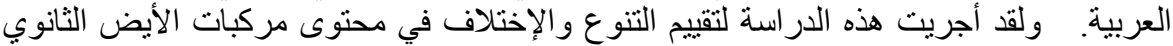

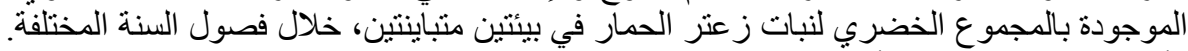

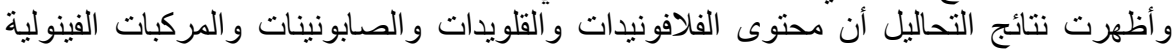

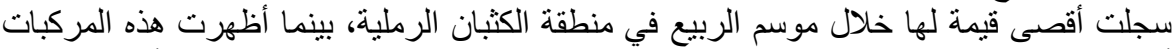

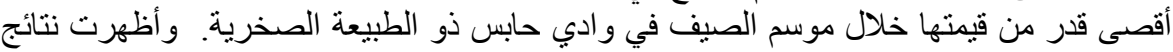

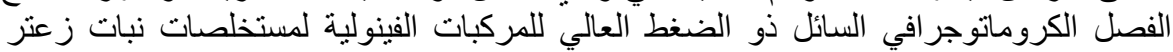

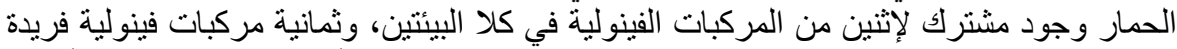

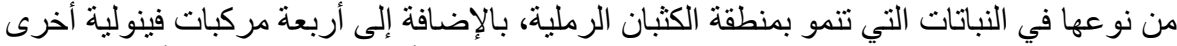

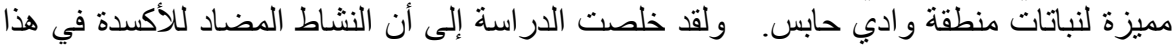
النبات يعزى إلى محتو اه العالي من المركبات التئ الفينولية.

Egyptian J. Desert Res., 66, No. 1, 1-16 (2016) 